\title{
Enhancement of Professional Behaviours and Perceptions of Critical Skill Job Preparedness through the Use of a Group Work Contract in Fourth-Year Nutritional Science Students
}

\author{
Nadia M. Cartwright ${ }^{1}$, Payal Patil ${ }^{1}$, Danyelle M. Liddle ${ }^{1}$, Genevieve Newton ${ }^{1}$ \& Jennifer M. Monk ${ }^{1}$ \\ ${ }^{1}$ Department of Human Health and Nutritional Sciences, University of Guelph, Guelph ON, N1G 2W1. Canada \\ Correspondence: Dr. Jennifer M. Monk, Department of Human Health and Nutritional Sciences, Animal Science and \\ Nutrition Building, Room 330B, University of Guelph, Guelph, Ontario, N1G 2W1, Canada.
}

Received: October 7, 2020

Accepted: November 13, 2020

Online Published: November 17, 2020

doi:10.5430/ijhe.v10n2p27

URL: https://doi.org/10.5430/ijhe.v10n2p27

Running Head: Use of a group work contract to improve group work collaboration

\begin{abstract}
Collaborative group assignments in undergraduate education are important for promoting skill development and preparation for the workplace; however, they are subject to the challenges associated with group dynamics. This research sought to determine the effectiveness of a Group Work Contract to facilitate professional behaviours and positive experiences amongst fourth year nutritional science students $(n=144)$ while working collaboratively to complete a Group Literature Critique Assignment designed to promote scientific literacy and critical thinking skills. Changes in students' attitudes and approaches to group work were assessed before and after completion of the contract and the assignment via two online surveys (Pre- and Post-Group Work Surveys). Completion of the Group Work Contract improved group dynamics including i) frequency of communication, ii) distribution of effort between group members, iii) mutual reliability, iv) respectfulness and inclusivity. Students also reported fewer group problems and an improved ability to work collaboratively in problem solving $(P<0.05)$. Importantly, students reported reduced feelings of anxiety related to group learning and perceptions of achieving a better outcome versus working alone and learning more as a result of working in a group $(P<0.05)$. Additionally, students reported an improvement in their job readiness perceptions with respect to the development of their scientific literacy and critical thinking skills as a result of completing the Group Literature Critique Assignment $(P<0.05)$. Collectively, this data demonstrates that structuring the group work process through the implementation of a Group Work Contract can support the development of positive and effective group dynamics resulting in reduced student anxiety about collaborative learning and perception of a better overall outcome.
\end{abstract}

Keywords: group work, professional behaviours, student anxiety, job readiness, scientific literacy, critical thinking

\section{Introduction}

Following completion of an undergraduate degree in nutritional science, it is expected that graduates will have developed a well-established set of skills that adequately prepare them for continued education or direct employment (Newton, Bettger, Buchholz, Kulak, \& Racey, 2015; Rose, 2013). More specifically, this includes attainment of competency in problem solving, critical thinking, scientific literacy and collaboration, which represent widely transferable skills across academic disciplines and in the workplace, and are therefore highly valuable skills for new graduates (Bridgstock, 2009; Newton et al., 2015; Sibley, Roche, Bell, Temple \& Wittmeier, 2017; Snell, Gatt, \& Gekara, 2016; Wensing \& Grol, 2019). Problem solving is the identification and resolution of an issue (Fero, Witsberger, Wesmiller, Zullo, \& Hoffman, 2009), whereas critical thinking extends to the active incorporation of previous observations and experiences to effectively interpret, analyze and evaluate new information to make better informed decisions (Facione, 1990). Scientific literacy is an essential skill comprised of multiple components including literature identification and analysis (Council of Ministers of Education, 1997; De Boer, 2000; Mayer, 1997; National Research Council, 1996); scientific comprehension and interpretation (Anderson, 1999; Phillips, 2002; Sutman, 1996) and knowledge utilization to draw evidence based conclusions (De Boer, 2000; Korpan, Bisanz, Bisanz, \& Henderson, 1997; Organisation for Economic Co-operation and Development, 2003; Shamos, 1995). Group work or collaboration aids in the development of student's communication and interpersonal skills while providing students with experience 
in behaving professionally and working cooperatively (Burdett, 2003; Curşeu, Janssen, \& Raab, 2012; Morgeson, Reider, \& Campion, 2005; Volkov \& Volkov, 2007). To address these post-graduation expectations, teaching nutritional science at the undergraduate level should promote high-level individual skill development in addition to meeting the course learning objectives (Newton et al., 2015).

Universities are responding to an increased need to develop students' experiences in group work in order to ensure their graduates' employability and compatibility in the workforce (Burdett, 2003). Recently, as an educational response to changes in skill demands following graduation, there has been a shift away from individual work towards group collaboration (Eurofound, 2007; Gil \& Alcover, 2008). Group work assignments and collaborative learning opportunities are used to recapitulate workplace expectations, yielding numerous benefits including knowledge acquisition, increased active learning opportunities and social skill development, which are key for both job promotion and job retention (Ismail \& Sabapathy, 2016). Structuring collaborative learning opportunities into courses has numerous benefits associated with both improving individual academic performance and attitudes towards course material (Davies, 1993; Johnson \& Johnson, 1989; Johnson \& Johnson, 1999; Walsey, 2006), facilitating critical skill development and providing students with the opportunity to initiate, form and maintain social educational relationships and outcomes (Payne, Monk-Turner, Smith \& Sumter, 2006; Tinto, 1993).

Therefore, students not only improve academically as a result of group work, but also improve their interpersonal and collaborative skills (Gillies, 2003; Morgeson et al., 2005). Similarly, group work has been shown to promote the development of critical thinking skills (McKeachie, Pintrich, Yi-Guang, \& Smith, 1986; McInerney \& Fink, 2003), scientific literacy (Auerbach \& Schussler, 2017; Liu, Liu, \& Lin, 2019; McInerney \& Fink, 2003; Monk \& Newton, 2017;), effective communication skills (Curşeu et al., 2012), social cognition (Solomon, Croft, \& Lawson, 2010) and improved self-efficacy (Johnson, Johnson \& Smith, 2007). Additionally, the active nature of group work promotes greater social support between group members and knowledge acquisition, which ultimately contributes to the success of collaborative work as a vehicle for skill development (Johnson et al., 2007) and optimally prepares undergraduate students for professional success post-graduation (Mendo-Lazaro, León-Del-Barco, Felipe-Castaño, Polo-Del-Rio, \& Iglesias-Gallego, 2018).

Despite the academic and professional benefits associated with the group work experience, negative consequences have been identified. Increased anxiety about group work is commonly experienced by students, largely caused by the potential impact of other group members on students' desired grade for the assigned task (Butt, 2017; Chang \& Brickman, 2018). This anxiety stems from common problems within group dynamics, which lead to disputes between group members (Butt, 2017). These anxiety-inducing concerns about group work can include frustration due to inequitable participation and contributions (Freeman \& Greenacre, 2010; Janssen, Erkens, Kanselaar, \& Jaspers, 2007; Livingstone \& Lynch, 2000), difficulties establishing group unity, and inconsistent work perceptions between group members (Freeman \& Greenacre, 2010; Le, Janssen, \& Wubbels, 2018). Additional challenges associated with group learning include varying skill levels and differing perceptions of work quality (Le et al., 2018), a lack of and/or ineffective communication (Li \& Campbell, 2008), and poor collaboration skills (Pauli, Mohiyeddini, Bray, Michie, $\&$ Street, 2008) between group members.

It is possible that the potential issues associated with group work could be adequately addressed through strategic group integration and intentional structuring of group work assignments to maximize knowledge attainment and skill development. Therefore, the objective of this study was to determine whether completion of a Group Work Contract associated with a Group Literature Critique Assignment could reduced student anxiety and common problems associated with group work dynamics. Since the assignment was intended to help students practise and develop scientific literacy and critical thinking skills, this study also assessed students' perceptions of their job readiness with respect to these skills.

\section{Methods}

\subsection{Participants}

Participants were undergraduate students enrolled in the course Toxicology, Nutrition and Food (NUTR*4510) in the Fall 2019 semester at the University of Guelph. The course was presented in a traditional 12-week face-to-face lecture format. $94 \%$ of students enrolled in the course were in the final year of their undergraduate program. All students who completed the online surveys in this study provided their informed consent to participate and the project was approved by the University of Guelph Research Ethics Board (REB\#19-07-003). As an incentive for participation, students received a $1 \%$ bonus on their midterm exam grade for completing the Start of Semester Survey and a $1 \%$ bonus on their final exam grade for completing the End of Semester Survey (described below). 


\subsection{Group Work Contract and Group Literature Critique Assignment}

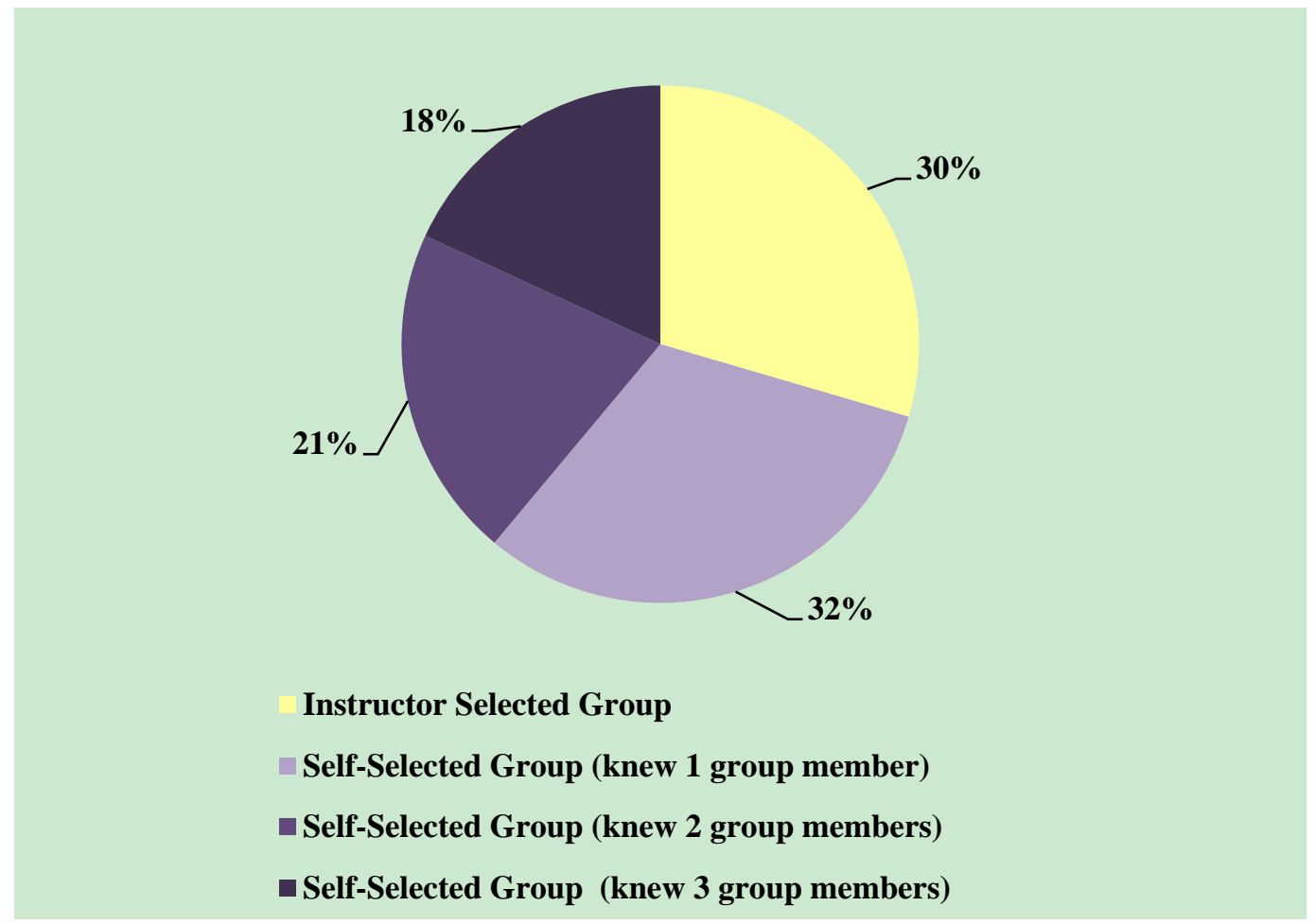

Figure 1. Distribution of students' in self-selected groups (students knew at least one or more group members) and instructor-selected groups (students did not know any group members) to complete the Group Literature Critique Assignment.

During the semester, students completed a written Group Literature Critique Assignment worth $25 \%$ of their final grade in the course. Prior to starting the assignment, groups were asked to complete and submit a Group Work Contract (Supplemental Materials), which consisted of a series of questions developed by the instructor intended to facilitate the group work process by prompting students to develop a plan for the distribution of work and a timeline for completing the assignment components in an organized manner with a professional group dynamic. The assignment required students to utilize both their scientific literacy and critical thinking skills in addition to working collaboratively to complete the final six-page written report. Students were instructed to select a topic of their choice related to nutritional toxicology and search the scientific literature to select four primary research articles that formed a small cluster of related research studies addressing their topic of interest. The submitted final assignment included i) a background summary of the topic, ii) a critical assessment of the strengths and limitations of the designs of the selected research studies, iii) interpretation and integration of the research findings from all selected research articles, iv) a discussion of how these studies contributed to the overall current understanding of their selected topic, and v) identification of current research gaps that included a proposed study design to address these research gaps identified by the students. To complete the assignment, students were instructed to work of groups of 4 and had the option of selecting their group members (i.e., self-selected groups). After 2 weeks, any students who were not already in a group were randomly assigned to group (i.e., instructor-selected groups). The breakdown of self-selected and instructorselected groups is shown in Figure 1, wherein $70 \%$ of students reported already knowing at least one of their group members prior to starting the assignment and 30\% of students reported not knowing any of their group members.

\subsection{Group Work Surveys}

At the start of the academic semester, students were invited by email using a private invitation link to complete the online Pre-Group Work Survey; a similar invitation to complete the Post-Group Work Survey was sent at the end of the 12-week semester. Both surveys were administered using the Qualtrics Insight Platform (Provo, UT, USA). Only students who completed both online surveys were included in the study $(n=144)$. Changes in the aggregate response to each survey question over the course of the academic semester were recorded (i.e. Post-Group Work Survey - PreGroup Work Survey). Students were asked questions pertaining to their attitudes and approaches related to group learning and group dynamics that were developed from the validated Group Work Survey published previously 
(Burdett, 2003). In the Pre-Group Work Survey, students were instructed to reflect on their previous experiences conducting group work, whereas in the Post-Group Work Survey, students were instructed to reflect on their experiences in engaging in the Group Literature Critique Assignment in the course NUTR*4510 that involved the implementation of a Group Work Contract. Students' responses to these questions were assessed using a scale of 1 through 5, which progressed as follows: 1 "strongly disagree", 2 "somewhat disagree", 3 "neither agree nor disagree", 4 "somewhat agree" and 5 "strongly agree". Additionally, the surveys consisted of non-validated researcher generated questions regarding students' perceptions about their i) scientific literacy and critical thinking skill development, ii) job readiness with respect to these skills for entering into the workforce in a career related to biological sciences, and iii) potential employers expectations for students to demonstrating these skills. Students were asked to answer each question using a scale of 0 through 10, that progressed as follows: 0 "strongly disagree", 1-2 "disagree", 3-4 "somewhat disagree", 5 "neither agree nor disagree", 6-7 "somewhat agree", 8-9 "agree" and 10 "strongly agree".

\subsection{Statistics}

All data were analyzed using Graphpad Prism 8.2.0 (GraphPad Software, Inc., La Jolla, CA, USA) and SPSS (IBM SPSS Statistics for Macintosh, Version 26.0., Armonk, NY, USA). The predetermined upper limit of probability for statistical significance was $P<0.05$. Values are expressed as means \pm SEM. The assumption of normality was assessed using the Shapiro-Wilk test. Paired t-tests were performed to determine the changes across time (i.e. changes between the Post-Group Work and Pre-Group Work Surveys) in response to scientific skill job readiness, professional behaviours and group dynamics in a collaborative group learning assignment and between self-selected and instructorselected group compositions. Pearson correlations were used to determine the association between students' professional behaviours, attitudes and approaches to group learning.

\section{Results}

\subsection{Changes in Students' Perceptions, Attitudes and Approaches to Group Learning}

The change in students' perceptions, attitudes and approaches to group learning over the course of the academic semester (i.e., change between the Pre- and Post-Group Work Surveys) are shown in Table 1. A frequently reported concern about group work is the inequitable distribution of effort between group members (Livingstone \& Lynch, 2000; Freeman \& Greenacre, 2010; Janssen et al., 2007), which can limit the associated benefits of collaboration (Johnson \& Johnson, 2009). The perception of equitable distribution of the work load between group members was significantly improved (Question 1, $P<0.05$ ), and in comparison to previous group learning experiences, students reported decreased perception of being required to complete the majority of work (Question 2, $P<0.05$ ). Effective communication underlies effective group learning dynamics and outcomes (Chang \& Brickman, 2018; Lewis, 2004), and students reported an increase in the frequency of group communication during the completion of the Group Literature Critique Assignment (Question 3, $P<0.05$ ). Moreover, students reported experiencing fewer problems as a result of conducting a structured group learning assignment through the implementation of a Group Work Contract (Question 4, $P<0.05$ ).

An effective group dynamic facilitates a positive learning experience (Brownlee \& Motowidlo, 2011). While there was no change in students' approach to assuming a leadership role while working in a group (Question 5, $P>0.05$ ), students reported improvements in various aspects related to the group dynamic including i) establishing positive working relationships with group members, ii) working collaboratively to solve problems, iii) the reliability of group members to meet deadlines, and iv) groups members being inclusive and respectful of each other's ideas (Questions 6-9, $P<0.05$ ).

The changes in the group dynamics resulted in improved overall outcomes from the group learning experience. Specifically, students reported achieving a better outcome overall and learning more as a result of working collaboratively versus working independently (Questions 10 and $11, P<0.05$ ). In this connection, there was a weak positive correlation between achieving a better outcome by working collaboratively (instead of independently) and i) groups that solved problems collaboratively $(\mathrm{r}=0.313, P<0.001)$, and ii) an equitable distribution of work between all group members $(\mathrm{r}=0.336, P<0.001)$. Moreover, there was a moderate positive correlation between achieving a better outcome as a result of working collaboratively and having reliable group members $(\mathrm{r}=0.557, P<0.001)$. Learning more as a result of collaboration (versus working alone) was weakly positively associated with i) working collaboratively to solve problems ( $\mathrm{r}=0.192, P=0.019)$ and ii) having reliable group members $(\mathrm{r}=0.294, P<0.001)$.

Student anxiety about collaborative or group learning assignments is a significant concern related to group work assignments (Cooper, Downing, \& Brownell, 2018). Importantly, as a result of utilizing the Group Work Contract, students reported feeling less anxiety or discomfort about working in a group and how it could impact their final grade (Question $12, P<0.05$ ). In this connection, student anxiety levels were weakly negatively correlated with perceptions 
of equitable distribution of work between group members ( $\mathrm{r}=-0.183, P=0.025)$. Moreover, student anxiety levels were negatively correlated with perceptions of i) having groups that worked collaboratively to solve problems ( $\mathrm{r}=-0.331$, $P<0.0001)$, and ii) having reliable group members ( $\mathrm{r}=-0.337, P<0.001)$.

\subsection{Changes in Group Work Dynamics between Self-Selected and Instructor-Selected Groups}

Within the class $70 \%$ of students were in self-selected groups, wherein they knew at least one or more of their group members prior to completing the Group Literature Critique Assignment and decided to work with their group members (Figure 1). Conversely, 30\% of the students were in instructor-selected groups, as they did not know any of their group members at the outset of the Group Literature Critique Assignment and were randomly assigned to their groups.

Table 1. Changes in students' professional behaviours, attitudes and approaches to group learning ${ }^{1}$

$\begin{array}{cccc}\text { Survey Question } & \text { Pre-Group } & \text { Post-Group } & \text { Mean Change in } \\ \text { Work Survey } & \text { Work Survey } & \text { Survey Responses }\end{array}$

\section{Distribution of Effort}

1. I completed the majority of the work

$3.58(0.06)$

$2.89(0.08)$

$-0.69 *$

2. The distribution of work was fair or

$3.42(0.09)$

$3.91(0.09)$

$+0.49^{*}$

equitable between all group members

Communication

3. There were frequent and/or regular group communication

4. I experienced fewer problems (e.g.

interpersonal disputes, incomplete work, etc.)

while conducting group work

\section{Group Dynamics}

5. I assumed a leadership role

$3.85(0.07)$

$3.70(0.08)$

$-0.15$

6. I established positive working relationships

$4.05(0.06)$

$4.32(0.08)$

$+0.27 *$

with group members

7. The group worked collaboratively to solve problem

$3.74(0.07) \quad 4.00(0.08)+0.26^{*}$

8. Group members were reliable

$3.66(0.08)$

$4.15(0.09)$

$+0.49^{*}$

9. Group members were inclusive and

respectful of each other's ideas

$4.38(0.06)$

$4.64(0.07)$

$+0.26^{*}$

\section{Outcomes}

10. I achieved a better outcome (e.g. grade, feedback), working collaboratively versus independently

11. I learned more as a result of collaborating in a group versus independently

12. I feel anxiety or discomfort when working on group assignments about how the group will

$2.88(0.08)$

$3.34(0.10)$

$+0.46^{*}$

affect my grade on the assignment

${ }^{1}$ Data are presented as means (SEM). An asterisk (*) represents statistically significant differences $(\mathrm{P} \leq 0.05)$ in student responses to each question during the academic semester is shown as the Mean Change in Survey Responses (i.e. PostGroup Work Survey - Pre-Group Work Survey). The survey scale for these questions was from 1-5, wherein 1 indicated the lowest level of agreement and 5 indicated the highest level of agreement.

Both self-selected and instructor-selected group compositions showed improvements in their perceptions, attitudes and approaches to group learning over the course of the academic semester (i.e., Post-Group Work Survey - Pre-Group Work Survey), however, the magnitude of the mean change in each of the group work-related survey questions was compared between these two types of group compositions, as shown in Table 2. As a result of the Group Work 
Contract, instructor-selected groups showed greater improvements in students perceptions of group members being more reliable $(P<0.001)$ and learning more as a result of collaborating in a group versus working independently $(P=0.002)$ in comparison to the improvements shown in the self-selected group compositions. Furthermore, in instructor-selected groups, wherein students did not know one another, the use of a Group Work Contract significantly reduced students reported feelings of anxiety or discomfort about how their group members would affect their grade on the assignment to a greater extent than the outcome in the self-selected group compositions $(P<0.001)$.

Table 2. Differences in students' attitudes and approaches to group learning in self-selected and instructor-selected group member compositions ${ }^{1}$

\begin{tabular}{ccc}
\hline Self-Selected & Instructor- & $P$-value \\
Groups & Selected Groups & \\
Mean Change & Mean Change \\
between the Post- & between the Post- \\
and Pre-Group & and Pre-Group \\
Work Surveys & Work Surveys \\
\hline
\end{tabular}

\section{Distribution of Effort}

1. I completed the majority of the work

$\begin{array}{lll}-0.62 & -0.84 & 0.31 \\ +0.41 & +0.68 & 0.33\end{array}$

2. The distribution of work was fair or equitable

$$
+0.41
$$

$+0.68$

0.33

\section{Communication}

3. There were frequent and/or regular group

$$
+0.33
$$

$+0.52$

0.39 communication

4. I experienced fewer problems (e.g.

interpersonal disputes, incomplete work, etc.)

while conducting group work

\begin{tabular}{|c|c|c|c|}
\hline 5. I assumed a leadership role & -0.08 & -0.37 & 0.14 \\
\hline $\begin{array}{l}\text { 6. I established positive working relationships } \\
\text { with group members }\end{array}$ & +0.21 & +0.40 & 0.32 \\
\hline $\begin{array}{l}\text { 7. The group worked collaboratively to solve } \\
\text { problem }\end{array}$ & +0.19 & +0.43 & 0.27 \\
\hline 8. Group members were reliable & +0.43 & +0.61 & $<0.001$ \\
\hline $\begin{array}{l}\text { 9. Group members were inclusive and respectful } \\
\text { of each other's ideas }\end{array}$ & +0.21 & +0.41 & 0.20 \\
\hline \multicolumn{4}{|l|}{ Outcomes } \\
\hline $\begin{array}{l}\text { 10. I achieved a better outcome (e.g. grade, } \\
\text { feedback), working collaboratively versus } \\
\text { independently }\end{array}$ & +0.4 & +0.50 & 0.81 \\
\hline $\begin{array}{l}\text { 11. I learned more as a result of collaborating in } \\
\text { a group versus independently }\end{array}$ & +0.28 & +0.50 & 0.002 \\
\hline $\begin{array}{l}\text { 12. I feel anxiety or discomfort when working on } \\
\text { group assignments about how the group will } \\
\text { affect my grade on the assignment }\end{array}$ & -0.75 & -1.06 & $<0.001$ \\
\hline
\end{tabular}

\section{Group Dynamics}

${ }^{1}$ Data are presented mean changes in survey responses between the Post-Group Work and Pre-Group Work Surveys in student groups comprised of self-selected group members (i.e., students who knew at least one or more of their group members and chose to work in that group; $70 \%$ of the class) and instructor-selected group members (i.e., students know did not know any of their group members and were randomly assigned to their group by the course instructor; $30 \%$ of the class). The survey scale for these questions was from 1-5, wherein 1 indicated the lowest level of agreement and 5 indicated the highest level of agreement. 
3.3 Changes in Students' Perceptions and Attitudes Regarding Scientific Literacy Development and Job Readiness between the Pre- and Post-Group Work Surveys

The results from the portions of the Pre- and Post-Group Work Surveys on students' perceptions and attitudes regarding their job readiness with respect to scientific literacy skills are shown in Table 3 (Questions 13-16). With respect to students' perceptions on the importance of developing scientific literacy skills in order to obtain a job in the field of biological science, there was no change over the course of the academic semester $(P>0.05)$. Students showed the greatest improvements in their feelings of scientific literacy job readiness in the field of biological science over the course of the semester $(P<0.05)$, increasing from $23.1 \%$ to $47.7 \%$ of students.

Table 3. Changes in perceptions of scientific literacy and critical thinking capabilities, job readiness and skill relevance $^{1}$

$\begin{array}{lccc}\text { Survey Question: } & \text { Pre-Group } & \text { Post-Group } & \text { Mean Change in } \\ \text { Work Survey } & \text { Work Survey } & \text { Survey Responses }\end{array}$

\section{Scientific Literacy}

13. I believe developing scientific literacy skills are important for obtaining a job in the field of biological science.

14. With respect to my scientific literacy capabilities, I feel prepared for a job in the field of biological science.

15. I believe future employers would expect me to have and demonstrate scientific literacy skills.

16. With respect to my scientific literacy capabilities, I feel I have had the opportunity to develop these skills during my undergraduate program.

\section{Critical Thinking}

17. I believe developing critical thinking skills are important for obtaining a job in the field of biological science.

18. With respect to my critical thinking capabilities, I feel prepared for a job in the field of biological science.

19. I believe future employers would expect me to have and demonstrate critical thinking skills.

20. With respect to my critical thinking $8.73(0.12)$ $8.67(0.12)$ $-0.06$ capabilities, I feel I have had the opportunity to

$5.94(0.19)$

$7.09(0.15)$ $+1.15^{*}$

$8.39(0.14)$

$8.33(0.14)$ $-0.06$

$7.46(0.16)$

$7.97(0.14)$ $+0.51^{*}$ $8.77(0.12)$ $8.73(0.10)$ $-0.04$ $6.36(0.16)$ $7.34(0.14)$ $+0.98^{*}$ develop these skills during my undergraduate program.

${ }^{1}$ Data are presented as means (SEM). $(*)$ represents statistically significant differences $(\mathrm{P} \leq 0.05)$ in student responses to each question during the academic semester is shown as the Mean Change in Survey Responses (i.e. Post-Group Work Survey - Pre-Group Work Survey). The survey scale for these questions was from 1-10, wherein 1 indicated the lowest level of agreement and 10 indicated the highest level of agreement.

With respect to students' perceptions of employers' expectations for employees or job candidates to demonstrate scientific literacy competency, there was no change during the semester; however, the level of agreement that demonstration of scientific literacy capabilities is an expectation of potential employers was already high at $97 \%$ of students. Importantly, the perception of having had the opportunity to develop scientific literacy skills during their undergraduate program increased from $70 \%$ of students at the start of the semester (which is reflective of past learning experiences) to $86 \%$ at the end of the semester, reflective of recent or additional scientific literacy skill building experiences in the current academic semester. 


\subsection{Changes in Students' Perceptions and Attitudes Regarding Critical Thinking Skill Development and Job Readiness} between the Start and End of the Semester

The results from the portion of the Pre- and Post-Group Work Surveys on students' perceptions and attitudes regarding job readiness with respect to critical thinking skills are shown in Table 3 (Questions 17-20). There was no change during the semester in students' perceptions regarding the importance of developing critical thinking skills in order to obtain a job in the field of biological science $(P>0.05)$. Students showed the greatest improvements in their perceptions of critical thinking job readiness over the course of the semester $(P<0.05)$, increasing from $27.2 \%$ to $53.4 \%$ of students. With respect to students' perceptions of employers' expectations for employees or job candidates to demonstrate critical thinking competency, there was no change; however, the level of agreement that demonstration of critical thinking capabilities is an expectation of potential employers was already high at the start of the semester with $94 \%$ of students in agreement. Importantly, students reported an increase over the academic semester in their perception of having had the opportunity to develop critical thinking skills during their undergraduate program, increasing from $73 \%$ of students at the start of the semester (reflective of past learning experiences) to $78 \%$ of students at the end of the semester, reflective of recent or additional critical thinking skill building learning experiences in the current academic semester.

\section{Discussion}

The current study assessed the changes in fourth-year nutritional science students' attitudes and approaches towards group work following the completion of a Group Work Contract intended to facilitate the development of an effective and successful group dynamic and to reinforce the development of collaborative skills and professional behaviours. Following the implementation of the Group Work Contract, students reported an improvement in their attitudes towards and experiences while conducting group work, which included categories of outcomes such as i) an equitable distribution of effort between group members, ii) greater reliability of group members, iii) improved communication with fewer interpersonal disputes between group members, and iv) improved group dynamics such as working collaboratively to solve problems and establishing positive working relationships that were inclusive and respectful. Collectively, as a result of engaging in a group work assignment structured by a Group Work Contract, students reported improved overall outcomes that included achieving a better outcome working in a group versus alone, learning more, and experiencing reduced anxiety about the impact of group work on their grades (Table 1). Moreover, since 94\% of students enrolled in the course were in the final year of their undergraduate program and the Group Literature Critique Assignment was intended to support skill development and an opportunity to practise their scientific literacy and critical thinking skills. Students reported that their job readiness perceptions with respect to these critical skills was significantly improved (Table 3). Collectively, these findings suggest a positive group dynamic and collaborative experience that supports critical skill development for the workplace.

In biological science undergraduate programs, development of critical skills that are widely transferable across academic disciplines are required to prepare students for continued education or entry into the workforce such as effective and professional collaboration skills, scientific literacy and critical thinking capabilities (Bridgstock, 2009; Snell et al., 2016; Newton et al., 2015; Wensing \& Grol, 2019; Sibley et al., 2017). Acquiring these skills in biological science education is important, as many careers that involve patient care, research inquiry, or further education have been shown to require competency in collaboration, problem-solving and critical thinking (Wensing \& Grol, 2019; Sibley et al., 2017). Experience in collaborative group work optimally prepares undergraduate students for professional success post-graduation (Mendo-Lazaro et al., 2018), perhaps because collaborative group work is a vehicle for skill development (Johnson et al., 2007) including critical thinking skills (McKeachie et al., 1986; McInerney \& Fink, 2003; Borich, 2004) and scientific literacy skills (Auerbach \& Schussler, 2017; Liu et al., 2019; McInerney \& Fink, 2003; Monk \& Newton, 2017) along with other important skills such as problem solving, communication and cooperative social skills (Borich, 2004). In the current study, students completed a Group Literature Critique Assignment intended to promote the development critical thinking and scientific literacy skills in a group learning environment, wherein their skill perceptions were improved with respect to attaining a level of proficiency associated with job readiness and entry into the workforce upon graduation (Table 3).

Social skills and interpersonal skills are required for effective outcomes when working in groups, and therefore, are central for establishing effective group dynamics and cohesion between group members (Morgeson et al., 2005; Stewart, Fulmer, \& Barrick, 2005). Moreover, the communication and social skills developed through group work are transferable to the workplace (Mendo-Lázaro et al., 2018). Group members must utilize these skills for effective communication and need to manage their behaviour when responding or reacting to their group members (Ferris, Witt, \& Hochwarter, 2001; Morgeson et al., 2005; Mumford, Peterson, \& Childs, 1999). Since working in groups increases 
the interdependence among group members to merge academic ideas and accomplish a task, there is greater potential for conflict and group members must work cooperatively to manage conflicts in an integrated manner, which highlights the importance for social and interpersonal skills to coordinate, work collaboratively, be dependable and distribute the workload among the group members (Campion, Medsker, \& Higgs, 1993; Morgeson et al., 2005). Some of these interpersonal and communication skills required to effectively work collaboratively to solve problems include, but are not limited to, adaptability, consideration, open-mindedness, conscientiousness, reliability, and helpfulness that permits working cooperatively with the intention of getting along and being respectful (Barrick \& Mount, 1991; Digman, 1990; Hogan \& Holland, 2003; Hurtz \& Donovan, 2000; Mendo-Lazaro et al., 2018; Morgeson et al., 2005; OECD 2017; Solomon et al., 2010). Importantly, group work provides an opportunity for students to develop these critical social and interpersonal skills which are key for both job promotion and job retention (Ismail \& Sabapathy, 2016). With respect to social skills assessed in the current study that underlie the establishment of an effective group dynamic, the use of a Group Work Contract promoted the perception of positive group dynamics resulting in the formation of groups with positive working relationships, group members that were reliable, worked collaboratively to solve problems and functioned in an inclusive and respectful manner (Table 1). These positive elements of group dynamics resulted in students achieving a better outcome overall and learning more as a result of working collaboratively in a group supported by a Group Work Contract then in comparison to their previous group learning experiences (Table 1). Moreover, these results highlight how facilitating the group work process by establishing behavioural expectations and increasing accountability within groups via the use of a Group Work Contract can help support positive group dynamics that reinforce professional behaviours, collaboration and social skills that translate to the workplace (Eurofound, 2007; Gil \& Alcover, 2008; Ismail \& Sabapathy, 2016; OECD, 2017).

Group work has been shown to promote the development of effective communication skills (Curşeu et al., 2012), including both social communication and academic written communication skills. Moreover, effective communication underlies the development of functional group learning dynamics and successful outcomes (Chang \& Brickman, 2018; Lewis, 2004), which were improved in the current study. Students reported that the Group Work Contract supported effective communication between group members, which included structuring expectations for frequent or regular group communication and experiencing fewer problems such as interpersonal disputes (Table 1). How individuals within a group prefer to communicate during the group work process is variable and can range from exclusively inperson meetings to entirely communicating through online platforms, or a combination of the two approaches. The use of technology and online communication platforms (email and text messaging) for academic conversations between students is frequent; however, a previous study identified that face-to-face conversations are preferred compared to all technological communication approaches (Swanson, Renes, \& Strange, 2018). Students in the current study reported that only $37 \%$ of their group communication was conducted through in-person face-to-face meetings despite the ability to physically meet during the semester, whereas $63 \%$ was conducted through online communication or collaboration platforms such as Google Docs, Microsoft Teams, E-mail and group messaging (i.e., text messaging or online messaging apps such as the use of Facebook Messenger or WhatsApp). It is important to note that this study was conducted prior to the emergency shift to online learning due to the COVID-19 pandemic, wherein subsequently the majority of undergraduate education has moved to online learning and in-person communication options are precluded (Dhawan, 2020; Marinoni, van't Land, \& Jensen, 2020). An important future direction will be to determine how students' attitudes and approaches towards online communication in collaborative learning settings change following the transition to remote learning, and how this impacts the development and implementation of group learning activities or assignments in undergraduate education. Moreover, as workplaces adapt and move towards an increased degree of remote work and online collaboration, students who were already engaging in online collaborative communication prior to COVID-19, as in the current study, may be more adequately equipped to adapt to online collaborative demands and expectations upon entry into the workplace. Thus, the increased degree of remote learning in higher education (Dhawan, 2020; Marinoni et al., 2020) may enhance the job readiness of students.

The emotions students feel linked to their academic achievement are referred to as "achievement emotions" (Brigati, England \& Schussler, 2020), wherein anxiety is the most commonly reported emotion expedienced (Pekrun, Goetz, Titz, \& Perry, 2002). Anxiety can have obvious negative impacts on student success and learning outcomes (Akgun \& Ciarrochi, 2003; Barthelemy, Hedberg, Greenberg, \& McKay, 2015; England, Brigati, Schussler, \& Chen, 2019; Witt, Schrodt, Wheeless, \& Bryand, 2014; Zusho, Pintrich, \& Coppola, 2003). How students cope with anxiety can differ, as some will respond to anxiety as a motivational stimulus to improve their performance (Baum, Singer, \& Baum, 1981; Brigati et al., 2020), whereas other students' response and subsequent outcomes will be negative. Coping behaviours most commonly employed by students experiencing anxiety during group work were support-seeking, such as creating a friendly or social supportive group dynamic to ease anxious tensions within the group (Brigati et al., 
2020). This commonly used approach emphasizes the importance of collaborative social skills in contributing towards a successful group work experience or group dynamic (Campion, Medsker, \& Higgs, 1993; Mendo-Lazaro et al., 2018; Morgeson et al., 2005; OECD, 2017; Stewart et al., 2005). Alternatively, some students utilize maladaptive coping behaviours in response to anxiety in group learning including escape, isolation or withdrawal from the group, thereby missing out on the benefits of the group learning activity (Brigati et al., 2020). Student anxiety about collaborative or group learning assignments is a logical and significant concern related to group work assignments, particularly with respect to the impact of other students on their grade (Cooper et al., 2018). In the current study, with the implementation of a Group Work Contract, students' anxiety levels were reduced and this beneficial effect was positively associated with functional group dynamics including i) working collaboratively to solve problems, ii) having group members that were reliable, and iii) an equal distribution of work between group members. By anticipating the negative impact of anxiety on student learning (Akgun \& Ciarrochi, 2003; Barthelemy et al., 2015; Cooper et al., 2018; England et al., 2019; Witt et al., 2014; Zusho et al., 2003) and implementing a structured approach to group learning assignments via a Group Work Contract to attenuate student anxiety levels, the educational emphasis can now be placed on learning outcomes of the assignment and allows group work to serve as a vehicle for critical skill development (Johnson et al., 2007).

Previous studies have successfully implemented the use of a Group Work Contract to structure the group work process and to optimize the group work learning experience (Ribner, 1974; Volet \& Mansfield, 2006; Zhang, Huang, \& Peng, 2018). Groups supported by an explicit contract are associated with an environment that supports both personal and collective growth, improved clarification of appropriate behaviour expectations and collaboration, and members' positive attitudes towards their group which increased their individual ability to participate in the group activity (Ribner, 1974; Zhang et al., 2018). Conversely, when a Group Work Contract permitted the eviction of a group member when conflict arose (as opposed to requiring students to work through the conflict) it reduced students' ability to negotiate and resolve conflicts (Volet \& Mansfield, 2006). Developing negotiation and conflict resolution skills are important components of collaboration, and group work provides an opportunity to develop and utilize these skills. Therefore, a Group Work Contract designed to help outline mitigation strategies and a course of action to resolve conflicts would need to strike an optimal balance outlined in the contract between student accountability and consequences for failing to uphold their responsibilities. The criteria to remove a student from the group should be outlined, however, to optimally support student skill development. An effective contract should require students to outline these criteria and develop a strategy to resolve conflicts that is implemented prior to the removal of a student from the group, as required by students utilizing the Group Work Contract in the present study. Despite the ability to remove a group member under specified conditions outlined by each group, it was never implemented by any participants in the current study. Thus, a Group Work Contract represents a useful approach to structure group work to facilitate the interaction between students and eliminate non-functional behaviour (Ribner, 1974), thereby permitting a group learning activity to serve as a vehicle for critical skill development (Johnson et al., 2007).

When conducting group work there are benefits associated with both self-selected and instructor-selected group members. Previous studies have shown that when students are able to select their group members, the primary criterion that they rely upon when forming groups is having a pre-existing friendship, which is perceived to facilitate communication, cooperation and proved satisfaction with the outcome of group work (Bacon, Stewart \& Silver, 1999; Chapman, Meuter, Toy \& Write, 2006; Hassaskhah \& Mozaffari, 2015; Mahenthiran \& Rouse, 2000; Mushtaq, Murteza, Rashid \& Khalid, 2012; Russell, 2010). Due to the pre-existing social relationships between group members in self-selected groups there can be challenges with remaining on task while conducting group work (Hassaskhah \& Mozaffari, 2015; Mitchell, Reilly, Bramwell, Solnosky \& Lilly, 2004) and lower acquisition of skills (Basta, 2011) compared to instructor-assigned groups. Furthermore, despite a frequent negative initial reaction to instructor-assigned groups, a functional group dynamic is achieved with satisfactory cooperation resulting in a positive outcome overall (Hassaskhah \& Mozaffari, 2015; Hilton \& Philips 2008). In the current study the formation of groups permitted students to self-select their group members, wherein $70 \%$ of students knew at least one or more group members socially prior to conducting group, wherein the remaining $30 \%$ of students who did not form a group were instructor-selected to work together on the Group Literature Critique Assignment. Despite having a beneficial effect on students' attitudes and approaches towards group work, the use of a Group Work Contract in instructor-selected groups resulted in greater improvements in students' perceptions of group members being more reliable and learning more as a result of collaborating in a group compared to students in self-selected groups (Table 2). Importantly, the reduction in students' anxiety about how their group members would affect their grade on the group assignment in instructor-selected groups was greater compared to students in self-selected groups (Table 2). This likely reflects the higher baseline levels of anxiety reported by students in instructor-selected groups due to the uncertainty of working with unfamiliar group 
members, however, the results demonstrate the utility of the Group Work Contract to facilitate the group work process and the development of positive group dynamics and approaches towards conducting group work.

Collectively, the results from the current study show that facilitating the group work learning experience via a Group Work Contract can support the establishment of effective group dynamics and communication, resulting in improved outcomes overall, reduced anxiety levels and enhanced student learning. For students who have not fully developed the social collaborative and interpersonal skills necessary for effective group dynamics (Campion et al., 1993; MendoLazaro et al., 2018; Morgeson et al., 2005; OECD, 2017; Stewart et al., 2005), the Group Work Contract provides a framework that outlines behaviours and expectations that resulted in students exhibiting greater reliability and developing positive working relationships between group members, such that students worked collaboratively to solve problems in a respectful and inclusive manner. Importantly, by reducing the degree of interpersonal conflicts that can arise during group work, students were able to utilize the group assignment as intended, to develop their scientific literacy and critical thinking skills, such that their perceptions of their job readiness with respect to these skills were increased. Critical thinking, scientific literacy and collaboration have been identified as widely transferable skills across academic disciplines and in the workplace (Bridgstock, 2009; Newton et al., 2015; Sibley et al., 2017; Snell et al., 2016; Wensing \& Grol, 2019), all of which were addressed in the current study that was supported by the use of a Group Work Contract to facilitate group work and allow for the development of critical skills during collaboration. Therefore, the implementation of a Group Work Contract may be beneficial if widely adopted across levels of undergraduate education.

\section{Acknowledgements}

This project was supported by the COESP BioEd Research Grant awarded to J.M.M. and an Undergraduate Research Assistantship from the University of Guelph awarded to N.M.C. D.M.L is supported by a NSERC graduate scholarship.

\section{References}

Akgun, S., \& Ciarrochi, J. (2003). Learned resourcefulness moderates the relationship between academic stress and academic performance. Education Psychology, 23(3), 287-94. https://doi.org/10.1080/0144341032000060129

Anderson, C. W. (1999). Inscriptions and science learning. Journal of Research in Science Teaching, 36(9), 973-974. https://doi.org/10.1002/(SICI)1098-2736(199911)36:9<973::AID-TEA1>3.0.CO;2-C

Auerbach, A., \& Schussler, E. (2017). Curriculum alignment with "vision and change" improves student scientific literacy. CBE Life Sciences Education, 16(2), ar29. https://doi.org/10.1187/cbe.16-04-0160

Bacon, D. R., Stewart, K. A., \& Silver, W. S. (1999). Lessons from the best and worst student team experiences: How a teacher can make the difference. Journal of Management Education, 23(5), 467-488. https://doi.org/10.1177/105256299902300503

Barrick, M. R., \& Mount, M. K. (1991). The big five personality dimensions and job performance: A metaanalysis. Personnel Psychology, 44(1), 1-26. https://doi.org/10.1111/j.1744-6570.1991.tb00688.x

Barthelemy, R. S., Hedberg, G., Greenberg, A., \& McKay, T. (2015). The climate experiences of students in introductory biology. Journal of Microbiology \& Biology Education, 16(2), 138-147. https://doi.org/10.1128/jmbe.v16i2.921

Basta, J. (2011). The role of the communicative approach and cooperative learning in higher education, Facta Universitatis Series: Linguistics and Literature, 9(2), 125-143.

Baum, A., Singer, J. E., \& Baum, C. S. (1981). Stress and the environment. Journal of Social Issues, 37(1), 4-35. https://doi.org/10.1111/j.1540-4560.1981.tb01056.x

Borich, G. D. (2004). Effective teaching methods, chapter 8: Indirect instruction strategies [Powerpoint slides]. Pearson Education, Inc. Retrieved from http://wps.prenhall.com/wps/media/objects/3134/3209449/ppts/chap08.ppt

Bridgstock, R. (2009). The graduate attributes we've overlooked: Enhancing graduate

employability through career management skills. Higher Education Research and Development, 28(1), 31-44. https://doi.org/10.1080/07294360802444347

Brigati, J. R., England, B. J., \& Schussler, E. E. (2020). How do undergraduates cope with anxiety resulting from active learning practices in introductory biology? PLoS ONE, 15(8), 1-23. https://doi.org/10.1371/journal.pone.0236558 
Brownlee, A. L., \& Motowidlo, S. J. (2011). Effects of accountability to group members and outcome interdependence on task behavior and interpersonal contextual behavior. Journal of Organizational Psychology, 11(1), 24-35.

Burdett, J. (2003). Making groups work: University students' perceptions. International Education Journal, 4(3), 177191.

Butt, A. (2017). Quantification of influences on student perceptions of group work. Journal of University Teaching and Learning Practice, 15(5), 1-15. https://doi.org/10.2139/ssrn.3001625

Campion, M. A., Medsker, G. J., \& Higgs, A.C. (1993). Relations between work group characteristics and effectiveness: Implications for designing effective work groups. Personnel Psychology, 46(4), 823-850. https://doi.org/10.1111/j.1744-6570.1993.tb01571.x

Chang, Y., \& Brickman, P. (2018). When group work doesn't work: Insights from students. CBE Life Sciences Education, 17(3), 1-17. https://doi.org/10.1187/cbe.17-09-0199

Chapman, K. J., Meuter, M., Toy, D., \& Write, L. (2006). Can't we pick our own group? The influence of group selection method on group dynamics and outcomes. Journal of Management Education, 30, 557-569. https://doi.org/10.1177/1052562905284872

Cooper, K. M., Downing, V. R., \& Brownell, S. E. (2018). The influence of active learning practices on student anxiety in large-enrollment college science classrooms. International Journal of STEM education, 5, 23. https://doi.org/10.1186/s40594-018-0123-6

Council of Ministers of Education, C. C. (1997). Common framework of science learning outcomes K to 12. Toronto: Council of Ministers of Education, Canada.

Curşeu, P. L., Janssen, S. E., \& Raab, J. (2012). Connecting the dots: Social network structure, conflict, and group cognitive complexity. Higher Education, 63(5), 621-629. https://doi.org/10.1007/s10734-011-9462-7

Davis, B. G. (1993). Tools for teaching. San Francisco, CA: Jossey-Bass Inc.

De Boer, G. E. (2000). Scientific Literacy: Another look at its historical and contemporary meanings and its relationship to science education reform. Journal of Research in Science Teaching, 37(6), 582-601. https://doi.org/10.1002/1098-2736(200008)37:6<582::AID-TEA5>3.0.CO;2-L

Dhawan, S. (2020). Online learning: A panacea in the time of COVID-19 crisis. Journal of Educational Technology, 49(1), 5-22. https://doi.org/10.1177/0047239520934018

Digman, J. M. (1990). Personality structure: Emergence of the five-factor model. Annual Review of Psychology, 41(1), 417-440. https://doi.org/10.1146/annurev.ps.41.020190.002221

England, B. J., Brigati, J. R., Schussler, E. E., \& Chen, M. M. (2019). Student anxiety and perception of difficulty impact performance and persistence in introductory biology courses. CBE-Life Science Education, 18(2), 1-13. https://doi.org/10.1187/cbe.17-12-0284

Eurofound. (2007). Teamwork and high performance work organization. Dublin, Ireland: European Foundation for the Improvement of Living and Working Conditions:

Facione, P. A. (1990). Critical thinking: A statement of expert consensus for purposes of educational assessment and instruction. Millbrae, CA: The California Academic Press;

Fero, L. J., Witsberger, C. M., Wesmiller, S. W., Zullo, T. G., \& Hoffman, L. A. (2009). Critical thinking ability of new graduate and experienced nurses. Journal of Advanced Nursing, 65(1), 139-148. https://doi.org/10.1111/j.1365-2648.2008.04834.x

Ferris, G. R., Witt, L. A., \& Hochwarter, W. A. (2001). Interaction of social skill and general mental ability on job performance and salary. Journal of Applied Psychology, 86(6), 1075-1082. https://doi.org/10.1037/00219010.86.6.1075

Freeman, L., \& Greenacre, L. (2010). An examination of socially destructive behaviors in group work. Journal of Marketing Education, 33(1), 5-17. https://doi.org/10.1177/0273475310389150

Gil, F., \& Alcover, C. M. (1998). Introduction to group psychology. Madrid: Pyramid.

Gillies, R. M. (2003). Structuring cooperative group work in classrooms. International Journal of Educational Research, 39(1-2), 35-49. https://doi.org/10.1016/S0883-0355(03)00072-7 
Hassaskhah, J., \& Mozaffari, H. (2015) The impact of group formation method (student-selected vs. teacher-assigned) on group dynamics and group outcome in EFL creative writing. Journal of Language Teaching and Research, 6(1), 147-156. http://dx.doi.org/10.17507;jltr.0601.18

Hilton, S., \& Philips, F. (2008). Instructor-assigned and student-selected groups: A view from inside. Issues in Accounting Education, 25(1), 15-33. https://doi.org/10.2308/iace.2010.25.1.15

Hogan, J., \& Holland, B. (2003). Using theory to evaluate personality and job-performance relations: A socioanalytic perspective. Journal of Applied Psychology, 88(1), 100-112. https://doi.org/10.1037/0021-9010.88.1.100

Hurtz, G. M., \& Donovan, J. J. (2000). Personality and job performance: The big five revisited. Journal of Applied Psychology, 85(6), 869-879. https://doi.org/10.1037/0021-9010.85.6.869

Ismail, N., \& Sabapathy, C. (2016). Workplace simulation: An integrated approach to training university students in professional communication. Business and Professional Communication Quarterly, 79(4), 487510. https://doi.org/10.1177/2329490616660814

Janssen, J., Erkens, G., Kanselaar, G., \& Jaspers, J. (2007). Visualization of participation: Does it contribute to successful computer-supported collaborative learning? Computers and Education, 49(2007), 1037-1065. https://doi.org/10.1016/j.compedu.2006.01.004

Johnson, D. W., \& Johnson, R. (1989). Cooperation and competition: Theory and research. Edina, MN: Interaction Book Company.

Johnson, D. W., \& Johnson, R. T. (1999). Making cooperative learning work. Theory into Practice, 38(2), 67-73. https://doi.org/10.1080/00405849909543834

Johnson D. W., \& Johnson R. T. (2009). An educational psychology success story: Social interdependence theory and cooperative learning. Educational Researcher, 38(5), 365-379. https://doi.org/10.3102/0013189X09339057

Johnson, D. W., Johnson, R. T., \& Smith, K. (2007). The state of cooperative learning in postsecondary and professional settings. Educational Psychology Review, 19(2007), 15-29. https://doi.org/10.1007/s10648-0069038-8

Korpan, C. A., Bisanz, G. I., Bisanz, J., \& Henderson, J. M. (1997). Assessing literacy in science: Evaluation of scientific news briefs. Science Education, 81(5), 515-532. https://doi.org/10.1002/(SICI)1098237X(199709)81:5<515::AID-SCE2>3.0.CO;2-D

Le, H., Janssen, J., \& Wubbels, T. (2016). Collaborative learning practices: Teacher and student perceived obstacles to effective student collaboration. Cambridge Journal of Education, 48(1), 103-122. https://doi.org/10.1080/0305764X.2016.1259389

Lewis, K. (2004). Knowledge and performance in knowledge-worker teams: A longitudinal study of transactive memory systems. Management Science, 50(11), 1519-1533. https://doi.org/10.1287/mnsc.1040.0257

Li, M., \& Campbell, J. (2008). Asian students' perceptions of group work and group assignments in a New Zealand tertiary institution. Intercultural Education, 19(3), 203-216. https://doi.org/10.1080/14675980802078525

Liu, Q., Liu, B., \& Lin, Y. (2019). The influence of prior knowledge and collaborative online learning environment on students' argumentation in descriptive and theoretical scientific concept. International Journal of Science Education, 41(2), 165-187. https://doi.org/10.1080/09500693.2018.1545100

Livingstone D., \& Lynch K. (2000). Group project work and student-centered active learning: Two different experiences. Studies in Higher Education, 25(3), 325-345. https://doi.org/10.1080/713696161

Mahenthiran, S., \& Rouse, P. J. (2000). The impact of group selection on student performance and satisfaction. Scholarship and Professional Work - Business, 185, 255-265. http://dx.doi.org/10.1108/09513540010348043

Marinoni, G., van't Land, H., \& Jensen, T. (2020). The impact of COVID-19 on higher education around the world: IAU global survey report. France: International Association of Universities.

Mayer, V. J. (1997). Global science literacy: An earth system view. Journal of Research in Science Teaching, 34, 101105. https://doi.org/10.1002/(SICI)1098-2736(199702)34:2<101::AID-TEA1>3.0.CO;2-X

McInerney, M. J., \& Fink, L. D. (2003). Team-based learning enhances long-term retention and critical thinking in an undergraduate microbial physiology course. Microbiology Education, 4, 3-12. https://doi.org/10.1128/154288103X14285806229759 
McKeachie, W., Pintrich, P., Yi-Guang, L., \& Smith, D. (1986). Teaching and learning in the college classroom: A review of the research literature. Ann Arbor, MI: The Regents of the University of Michigan.

Mendo-Lázaro, S., León-Del-Barco, B., Felipe-Castaño, E., Polo-Del-Río, M., \& Iglesias-Gallego, D. (2018). Cooperative team learning and the development of social skills in higher education: The variables involved. Frontiers in Psychology, 9(1536). https://doi.org/10.3389/fpsyg.2018.01536

Mitchell, S. N., Reilly, R., Bramwell, G., Solnosky, A., \& Lilly, F. (2004). Friendship and choosing groupmates: Preferences for teacher-selected vs. student-selected groupings in high school science classes. Journal of Instructional Psychology, 31(1), 20-32.

Monk, J. M., \& Newton, G. (2018). Use of scaffolded case study assignment to enhance students' scientific literacy skills in undergraduate nutritional science education: Comparison between traditional lecture and distance education course formats. International Journal of Higher Education, 7(2), 95-106. https://doi.org/10.5430/ijhe.v7n2p95

Morgeson, F. P., Reider, M. H., \& Campion, M. A. (2005) Selecting individuals in team settings: The importance of social skills, personality characteristics, and teamwork knowledge. Personnel Psychology, 58(3), 583-611. https://doi.org/10.1111/j.1744-6570.2005.655.x

Mumford, M. D., Peterson, N. G., \& Childs, R. A. (1999). Basic and cross-functional skills. In N. G. Peterson, N. G., Mumford, M.D., Borman, W. C. Jeanneret, P. R., \& Fleishman, E. A. (Eds.), An occupational information system for the 21st century: The development of $O^{*} N E T$ (p. 49-69). American Psychological Association. https://doi.org/10.1037/10313-004

Mushtaq, R., Murteza, G., Rashid, S., \& Khalid, A. (2012). The influence of group selection method on grades, performance and group outcome. Journal of Basic and Applied Scientific Research, 2(7), 7003-7008.

National Research Council. (1996). National science education standards. Washington, DC: The National Academies Press. https://doi.org/10.17226/4962

Newton, G., Bettger, W., Buchholz, A., Kulak, V., \& Racey, M. (2015). Evidence-informed strategies for undergraduate nutrition education: a review. Applied Physiology Nutrition, and Metabolism, 40(7), 652-661. https://doi.org/10.1139/apnm-2014-0368

OECD. (2015). PISA 2015 assessment and analytical framework: Science, reading, mathematic, financial literacy and collaborative problem solving. Paris: OCDE. https://doi.org/10.1787/9789264281820-en

Organisation for Economic Co-operation and Development. (2003). The PISA 2003 assessment framework: Mathematics, reading, science and problem solving knowledge and skills. Program for International Student Assessment. https://doi.org/10.1787/19963777

Pauli, R., Mohiyeddini, C., Bray, D., Michie, F., \& Street, B. (2008). Individual differences in negative group work experiences in collaborative student learning. Educational Psychology, 28(1), 47-58. https://doi.org/10.1080/01443410701413746

Payne, B. K., Monk-Turner, E., Smith, D., \& Sumter, M. (2006). Improving group work: Voices of students. Education, 126(3), 441-448.

Pekrun, R., Goetz, T., Titz, W., \& Perry, R. P. (2002). Academic emotions in students' self-regulated learning and achievement: A program of qualitative and quantitative research. Educational Psychologist, 37(2), 91105. https://doi.org/10.1207/S15326985EP3702_4

Phillips, L. (2002). Making new and making do: Epistemological, normative and pragmatic bases of literacy. In O.D.R., D. Kamawar \& J. Brockmeier (Eds.), Literacy and conceptions of language and mind, 283-300. Cambridge: Cambridge University Press.

Ribner, N. (1974). Effects of an explicit group contract on self-disclosure and group cohesiveness. Journal of Counseling Psychology, 2l(2), 116-120. https://doi.org/10.1037/h0036195

Rose, M. (2013). Preparing for life "beyond academe": Professional skills development for graduate students in Canadian universities. English Studies in Canada, 39(4), 4-8. https://doi.org/10.1353/esc.2013.0041

Russell, M. (2010). The formation of effective work groups within an FE classroom. Research in Post-compulsory Education, 15(2), 205-221. https://doi.org/10.1080/13596741003790765

Shamos, M. H. (1995). The myth of scientific literacy. New Brunswick, NJ: Rutgers University Press. 
Sibley, K. M., Roche, P. L., Bell, C. P., Temple, B., \& Wittmeier, K. (2017). A descriptive qualitative examination of knowledge translation practice among health researchers in Manitoba, Canada. BMC Health Services Research, 17(627). https://doi.org/10.1186/s12913-017-2573-9

Snell, D., Gatt, K., \& Gekara, V. (2016). Cross-occupational skill transferability: Challenges and opportunities in a changing economy. Adelaide, Australia: NCVER.

Solomon, Y., Croft, T., \& Lawson, D. (2010). Safety in numbers: Mathematics support centres and their derivatives as social learning spaces. Studies in Higher Education, 34(4), 421-431. https://doi.org/10.1080/03075070903078712

Stewart, G. L., Fulmer, I. S., \& Barrick, M. R. (2005). An exploration of member roles as a multilevel linking mechanism for individual traits and team outcomes. Personnel Psychology, 58(2), 343-365. https://doi.org/10.1111/j.1744-6570.2005.00480.x

Sutman, F. X. (1996). Scientific literacy: a functional definition. Journal of Research in Science Teaching, 33, 459460.

Swanson, J. A., Renes, S. L., \& Strange, A. T. (2018). The communication preferences of collegiate students. $15^{\text {th }}$ International Conference on Cognition and Exploratory Learning in Digital Age (CELDA 2018), 86-93.

Tinto, V. (1993). Leaving college: Rethinking the causes and cures of student attrition (2nd ed.). Chicago, IL: University of Chicago Press. https://doi.org/10.7208/chicago/9780226922461.001.0001

Volet, S., \& Mansfield, C. (2006). Group work at university: Significance of personal goals in the regulation strategies of students with positive and negative appraisals. Higher Education Research \& Development, 25(4), 341-356. https://doi.org/10.1080/07294360600947301

Volkov, A., \& Volkov, M. (2007). Teamwork and assessment: A critique. Journal of Business Education \& Scholarship of Teaching, 1(1), 59-64

Wasley, P. (2006). Underrepresented students benefit most from 'engagement.' The Chronicle of Higher Education, 53(13), p.A39.

Wensing, M., \& Grol, R. (2019). Knowledge translation in health: how implementation science could contribute more. BMC Medicine, 17(88), 1-6. https://doi.org/10.1186/s12916-019-1322-9

Witt, P. L., Schrodt, P., Wheeless, V. E., \& Bryand, M. C. (2014). Students' intent to persist in college: Moderating the negative effects of receiver apprehension with instructor credibility and nonverbal immediacy. Communication Studies, 65(3), 330-52. https://doi.org/10.1080/10510974.2013.811428

Zhang, L., Huang, S., \& Peng, Y. (2018). Collaboration in integrated project delivery: The effects of trust and formal contracts. Engineering Management Journal, 30(4), 262-273. https://doi.org/10.1080/10429247.2018.1498259

Zusho, A., Pintrich, P. R., \& Coppola, B. (2003). Skill and will: The role of motivation and cognition in the learning of college chemistry. International Journal of Science Education, 25(9), 1081-94. https://doi.org/10.1080/0950069032000052207

\section{Copyrights}

Copyright for this article is retained by the author(s), with first publication rights granted to the journal.

This is an open-access article distributed under the terms and conditions of the Creative Commons Attribution license (http://creativecommons.org/licenses/by/4.0/). 